\title{
Trade wars and the changing international order: a crisis of globalization?
}

\begin{abstract}
Increased geopolitical competition and growing economic nationalism after 2014 have gradually started to slow the trend of liberalization of international trade. Relations among certain national states have turned into trade wars - a hybrid phenomenon shaped at the intersection of geopolitics and geoeconomics. The paper explores global and regional trends in trade regulations introduced by the world's largest economies and, at the same time, its major military powers. The G20 countries' role in these processes was illustrated through references to empirical data on the dynamics of the introduced trade regulations in 2009-2018. The effectiveness of the regulations index is proposed. Apart from the harm that deepening such negative trends in the global geostrategic balance does to broader bilateral relations, the role of trade wars in re-shaping globalization's established conditions is also discussed.
\end{abstract}

Keywords

Geoeconomics $\cdot$ geopolitics $\cdot$ globalization $•$ G20 $\bullet$ trade wars

(C) University of Warsaw - Faculty of Geography and Regional Studies

Introduction

Trade wars are the main driver of changing conditions of globalization observed in the second decade of the $21^{\text {st }}$ century. They are widely manifested in great powers' tactical behavior, their re-defined priorities, and the shifting balance between their geopolitical and economic interests. As a measure of the strength and influence of nation states, geopolitics has traditionally focused on military power, resources and demography, while the priorities of the economy are growth, productivity and prosperity (Global Risks 2015). Despite these fundamental doctrinal differences, the current rapprochement between geopolitics and the economy is best reflected in the concept of trade wars - a diverse set of measures such as economic sanctions, trade tariff increases or the introduction of quantitative limits on imported goods utilized by national governments to strengthen their positions by weakening rivals or trading partners.

In geoeconomics, trade wars (Findlay \& O'Rourke 2007; Wigell 2016; Gens 2019) are treated as "the admixture of the logic of conflict with the methods of commerce" (Luttwak 1990, 19). Mair (2018) highlights two aspects of geoeconomics as international activity: 1) the use of political means to achieve economic goals (trade and investment agreements, state foreign trade promotion, governmental interference in securing raw materials, etc.); and 2 ) the use of economic means to achieve political goals (control of markets, trade surpluses and currency reserves, strategic investments, economic sanctions). Grossman and Helpman (1995) emphasize the role of trade negotiations and political pressure from interest groups on tariff rates. They argue that political lobbying of industries, as well as pressure from national governments, can significantly influence tariff barriers. Economic concepts are

\author{
Valentin Mihaylov $\mathbb{C}$, \\ Sławomir Sitek $\mathbb{0}$ \\ Institute of Social and Economic Geography and \\ Spatial Management, University of Silesia in Katowice, \\ Sosnowiec, Poland \\ e-mail: valentin.mihaylov@us.edu.pl \\ e-mail: slawomir.sitek@us.edu.pl \\ Received: 3 May 2020 \\ Accepted: 17 January 2021
}

dominated by opinions that point to the positive effects of the free exchange of goods and the movement of technology and people among countries, encouraging innovation and better meeting the social needs of their inhabitants. Nevertheless, as the growing number of tariffs in the 2010s has demonstrated, trade wars have additional effects on the economy through various intermediary channels, including a rise in the financing cost of capital caused by financial stress or a drop in investment due to uncertain business climate (Berthou et al. 2019). Apart from a large range of tariffs and paratariffs, protectionism remains a means of geopolitical pressure, including the economic weakening of hostile political regimes (Doxey 1980; Pape 1997).

Multidirectional effects of restrictive economic measures imply different reactions to, expectations of, and visions of the broader influence they have on the international order. In this article, the authors raise and try to clarify the question of whether we are facing a temporary situation or a radical, long-term reshaping of rules-based international trade relations, and how the recent policy of the most influential states may reverse the previous trend of liberalization and intentions to make a borderless world. The ways in which particular geopolitical interests change the post-Cold War foundations of globalization and world geography of economic ties are also discussed. Whereas barrier-free trade is ranked among the strongest symbols of modern globalization, the more specific purpose of the article is to examine how the use of the economy in the geopolitical strategies of the world's leading states affects their current participation in international trade and their mutual relations. The period of research is mostly limited to the second decade of the twenty-first century. Since the 
greatest part of recent academic literature is focused on analyzing US protectionist policies (Scott \& Glass 2016; Steinbock 2018; Medeiros 2019; Qui et al. 2019; Larres 2020), the authors aim to encapsulate this issue in a wider geographical scope by appropriate empirical references presenting protectionist measures undertaken and the reciprocal responses of other influential participants in global economic relations.

The article is structured as follows. The first section discusses how trade wars become part of the agenda of international problems and how this issue is interpreted by theoreticians, especially in the context of the thesis of a crisis of globalization. The next section describes the methods applied in the study and presents the sources of empirical data. The analytical part of our research is divided into two sections. Firstly, publicly accessible empirical data on the introduction of acts liberalizing and impeding trade among the world's largest economies (G20) are used to attempt to quantify and describe this phenomenon and to emphasize its deglobalizing effects. Further, in the second analytical section, the big picture of ongoing trade wars is outlined by a range of examples of mutually antagonistic measures between key international actors. The final section takes into consideration the obtained empirical results to draw the main conclusions regarding the dilemma about the future of globalization.

\section{Changing conditions of globalization, shifting} understandings of the international order

A growing number of scientists, politicians and social thinkers are warning that ongoing trade wars are driving the observed crisis of globalization (Hillebrand 2010; Yakovlev 2017; King 2018; ed. Diamond 2019; Amadi 2020). Looking back over the entire postCold War period, in processes of both international competition and cooperation, two phases that we associate with the waves of globalization and deglobalization (Karunaratne 2012) can be conventionally distinguished. Each of them is characterized by essential, if not radical, changes in previous conditions and the emergence of new megatrends, which have been variously assessed in scientific concepts in geopolitics, economy and political science.

The first phase began after the end of the Cold war. In that period, Fukuyama (1992) formulated the concept of "the end of history." It seemed that, with the disappearance of the global ideological conflict, the principles of liberalism would irreversibly dominate trade contacts between the actors involved in international politics and economic exchange. After many years of negotiations, China (in 2001) and Russia (in 2012) became members of the World Trade Organization. Apart from the recession in 2008-2009, the absence of global conflicts contributed to a several-fold increase in world trade - from 3.5 trillion USD in 1990 to 9.5 trillion USD in 2018 (The World Bank Web Site 2020). Not only China, but also other states from the Global South as India, Brazil, Turkey, Indonesia and Mexico - which more or less successfully have been adjusting their economic systems to accelerated global flows of goods, capitals and services - have an important share in this growth (Mukherji 2009; Kaplinsky \& Farooki 2011; Porzecanski 2015).

Regarding economic sanctions, they were a common tool of international relations in this phase, but they concerned countries of lesser importance to the global economy, such as Iraq, Yugoslavia, Haiti, Libya, Liberia, Rwanda or Sierra Leone (eds Bourantonis \& Wiener 1995; van Bergeijk 1995). Such sanctions influenced more than merely the economies and political systems of the affected countries. In fact, the trade wars of the 1990s were accompanied by military power, which had a decisive role in achieving formulated geopolitical purposes. Another peculiarity was that, in the first decade after the Cold War, major sanctions lists were imposed by the United Nations (Cortright \& Lopez 2000; Mack \& Khan 2000; Joyner 2003). Among the peculiarities of the international system is the fact that the world's greatest powers (in particular all the members of UN Security Council, which often use military means to defend their interests in various regions), have never been the target of sanctions introduced by the United Nations, in whose decision-making process they play a key role.

The removal of many barriers to transnational flows of capital, goods and services inspired the developing of a range of concepts for changing the global order. In addition to the term "time-space compression" (Harvey 1989), more radical labels describing the shifting global conditions appeared, i.e. "the death of geography" (McCabe 2012) and "the end of geography" (Greig 2002; Bethlehem 2014). In the context of the voluntary partial renunciation of state sovereignty (Luke 1996), the treatment of foreign policy in military and geopolitical terms was, if not completely eliminated, certainly pushed into the background. Consequently, some researchers were wondering if this would lead to the end of geopolitics (Toal 1997).

The initial contours of the second phase appeared with the financial crisis in 2008-2009. The World Economic Forum report on global economic risk in 2015 noted a reversal of previous trends. It is claimed that the present international environment is characterized by increasing efforts by nation states to gain relative power over others, even at the expense of their own economic interests. The development of trade in global networks and growing financial ties increased the economic costs of the growing protectionist policies (Global Risks 2015). The symbol of new times for global exchange was the return to the doctrine of sovereignty seen in Donald Trump's policy of economic nationalism (Evenett \& Fritz 2019). An evolution in the policy of international sanctions also occurred (Gottemoeller 2007). The "tit-for-tat" principle (Bongardt \& Torres 2018) in introducing tariffs, sanctions and other restrictions affected direct relations between the largest countries of the contemporary world. In this wave of trade wars, a leading role is played by governments that introduce sanctions against particular economic sectors, companies or politicians, including "smart" or "targeted" sanctions (Drezner 2003; Gordon 2011; Brzoska 2015).

In the new and not entirely predictable circumstances of global and regional geopolitics, it turned out that the proposition of the end of geography was something of a caricature (Bethlehem 2014). From the point of view of spatial order, the trend of the weakening of liberal politics, which was still visible in attempts at theoretical reflection after the financial crisis of 2008-2009 in international relations, served as an inspiration for the farreaching theses of "the revenge of geography" (Kaplan 2012), "the return of geopolitics" (Dieter 2014), "the return of history" (King 2018), or even "the end of globalization" (James 2001; Jacoby 2018; King 2018). Apart from the new geopolitical environment, the "crisis" and "disruption" of globalization (ed. Diamond 2019), as well as the new wave of "deglobalization" (Bello 2004; Hillebrand 2010; Karunaratne 2012), have been accelerated by the rise of populist movements' and states' desire to strengthen their sovereignty. Since 20142015 , the shifting structure of power and its possibilities to impact international affairs create both opportunities and risks for cooperation (National Security Strategy 2015). On the one hand, the internal cohesion of supranational organization is declining slightly, as evidenced by Brexit and its still unpredictable consequences. On the other hand, the multipolarity of the geopolitical and geoeconomic order is reinforced by alternative initiatives, i.e., the creation of the New Development Bank by members of the BRICS group (eds de Oliveira \& Jing 2020).

The 1990s were a period when geopolitical confrontation was replaced by open borders and economic cooperation, which contribute to the emergence of a hyper-connected world (Balsa- 
Barreiro et al. 2020) in conditions of hyperglobalization (Subramanian \& Kessler 2013). In turn, the wave of trade wars from the second half of the 2010s marked the opposite trend - a return to geopolitics and trade deglobalization. In terms of the economic consequences of the last wave of trade wars, compared to the geoeconomic clashes known from history, the past 30 years differ significantly. In a globalized economy, sanctioned countries have many more opportunities to evade unfriendly restrictions. Being importers and exporters of more goods and services, most countries have real opportunities to expand or create new trading partnerships in response to economic sanctions (Economic Sanctions. Sharpening a Vital Foreign Policy Tool 2017).

\section{Data and methods}

As indicated, the empirical part of the study covers two aspects of the current trade wars. The first concerns the number of protectionist and liberalizing acts introduced by and toward sovereign states. Their analysis for the period of 2009-2018 is based on data from Global Trade Alert, an organization ensuring "the most comprehensive coverage of policy changes affecting cross-border commerce" (Evenett 2019, p. 2). Attention was focused on the G20 countries, as their governments have the greatest influence on global geopolitical and geoeconomic relations.

An attempt was made to parameterize the overall relationship among the national states. The effectiveness of regulations was used to describe two types of relationships (Fig. 1):

- Type 1: The number of trade regulations that all countries have in place for a given country. This relationship shows how strong the attitude of all the countries of the world toward a given country is.

- Type 2: The number of trade regulations that a country has in place for all other countries in the world. It shows the policy of a country toward all other countries.

In both cases, the calculation algorithm was the same and included the number of regulations introduced to inhibit and liberalize trade. The procedure is based on the following formula:

$E R=\frac{\mathrm{H}-\mathrm{L}}{\mathrm{H}+\mathrm{L}} * 100 \%$

Where:

$E R$ - effectiveness of regulations

$H$ - regulations restricting trade

$L-$ regulations liberalizing the possibility of trade

Effectiveness of regulations indicates the extent to which the total balance of the regulations introduced translates into a clear direction of impact. Because restrictions prevail, it indicates an inhibiting effect. This indicator eliminates the impact of the number of regulations, since a significant number of inhibiting procedures with an equally large number of liberalizing regulations minimizes their impact. A lower result means that the effect is more neutral, whereas a higher value serves as evidence for the greater advantage of restrictive regulations.

The second aspect of trade wars under consideration is the introduction of sanctions or customs tariffs by countries and transnational organizations. Taking into account the increasing number of such measures targeted toward governments, economic sectors, particular companies and public persons, the empirical covering of this phenomenon and their geoeconomic and geopolitical effects cannot be comprehensively covered for all countries in the world. For that reason, we have limited our analysis mainly to restrictive measures introduced by the USA, China, the EU, Russia and some other geopolitically important
Type 1 relationship

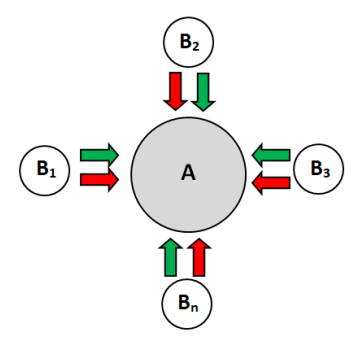

Type 2 relationship

A - country $A$

$B_{1}, B_{2}, B_{3}, \ldots B_{n}$ - other countries

$\Rightarrow$ regulations liberalizing the possibility of trade

regulations restricting trade

Figure 1. Types of trade relations between countries Source: elaborated by the authors

states, complemented by a World Bank data analysis showing ongoing changes in exports and imports. On the example of these several cases, we outline the effects (already targeted or potential) of trade wars on imports and exports, as well as on the forced reconfiguration of the geographical structure of trade flows. The megatrends of breaking economic ties between both rivals and close allies in international politics and the widely applied "tit-for-tat" principle are evidenced by empirical data of their ongoing contribution in providing trade barriers.

Trade restrictions between the largest world economies

Up until the middle of the second decade of the $21^{\text {st }}$ century, there was a clear tendency for political and economic barriers hindering international flows of goods, services and capital to decrease. However, the liberalizing tendency began to slow in the mid-2010s. A number of political and economic phenomena coincided that began increasingly to undermine the rules of the game in the international order formed after the Cold War. In this section, taking into consideration the demographic weight, importance to international trade and geopolitical profile of the $\mathrm{G} 20$ members, the authors analyze the chief empirical peculiarities in providing harmful and liberalizing regulations from a geoeconomic and geopolitical point of view.

In the period following the global financial crisis (Fig. 2), the number of regulations affecting the trade process generally increased. The maximum value was recorded at the end of the period of investigation, when 2.169 restrictive acts were introduced. Nevertheless, in 2018 and 2019, only the US and China introduced reciprocal restrictions, which are not as numerous but are of an incomparably high magnitude. At the beginning of 2020, the total amount of trade affected by US tariffs on Chinese goods was as high as USD 550 trillion. On the other hand, China introduced restrictions for US goods in the amount of USD 185 trillion (The US-China Trade War: A Timeline 2020). As indicated in the report "Going It Alone? Trade Policy After Three Years of Populism" (2019, p. 14), "before the Populist era, China and the United States were responsible for 'only' $12 \%$ of global totals for discrimination against foreign commercial interests." In comparison, between 2017 and 2019 the two biggest economies together were responsible for $23 \%$ of the world's newly implemented protectionist measures.

In the entire period, inhibitory measures prevailed. They serve as evidence of deglobalizing trends. The greatest disproportion was recorded in 2018 , when the share of liberalizing regulations was as low as $24 \%$ (Fig. 2). In turn, the situation was most favorable in 2016. Liberalization decrees accounted for 


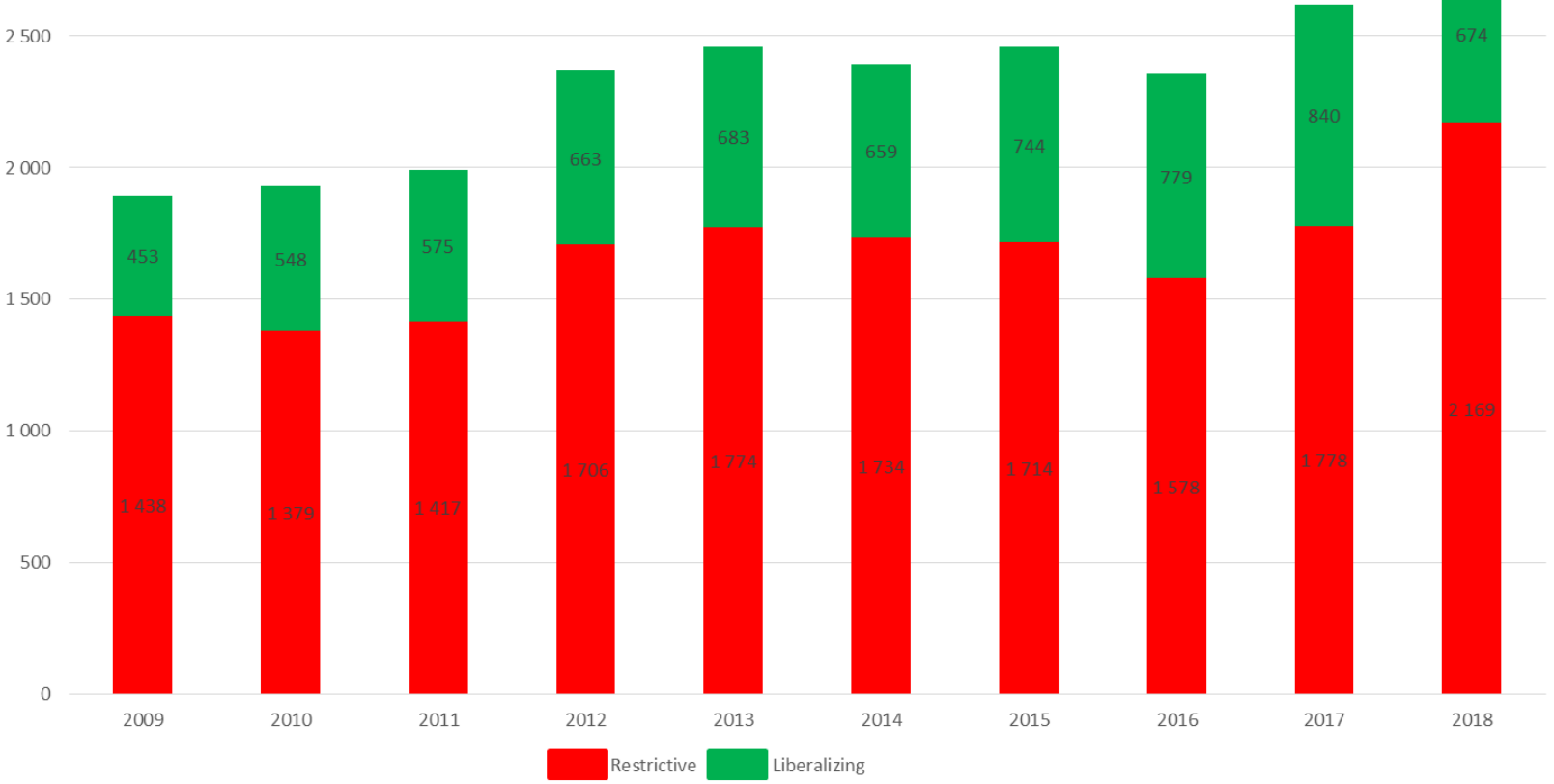

Figure 2. Trade regulations between countries worldwide (2009-2018) Source: own elaboration based on Global Trade Alert data (www.globaltradealert.org)

over $33 \%$ of all regulations. In the whole analyzed period, the largest share of restrictions (almost 40\%) concerned subsidies (excluding export subsidies) - bailouts, state loans, financial grants, tax or social insurance relief, etc. These are followed by export-related measures $(20.3 \%)$ - export quotas, export bans, tax-based export incentive; tariff measures (13.6\%); and contingent trade-protective measures $(10.6 \%)$.

There was a great convergence between the number of regulations hindering trade and those facilitating it, i.e. the observed increases or decreases in such decisions were parallel. This may indicate close links in the global economy that require a constant search for new partners and markets. These regulations are therefore a mechanism that changes the direction of the flow of goods. However, their causes are not market-related, but they are regulatory and result from geopolitical decisions. The increasing number of regulatory acts can be associated with the rapid growth of trade. Nonetheless, this is just one of the possible explanations. Evenett (2019) provides evidence for the growing importance of protectionism, which is undoubtedly among the main drivers of trade wars. The author specifies that, in 2018, $61 \%$ of world goods exports competed against a foreign firm whose government was making available a financial inducement to export. Over $34 \%$ of world goods exports in 2018 faced other (non-export-related) trade distortions in third markets. A fifth of world goods exports competed in foreign markets against a local firm bailed out or in receipt of another form of financial aid from the government (Evenett 2019).

In Type 1 trade relations, acts that hamper economic exchange are most common, as confirmed by the overview for G20 countries (Table 1). The number of regulations does not always correlate with the state's demographic potential or the openness of the national economy, e.g. France, Italy, South Korea and Canada are subject to a large number of restrictions imposed by other countries. The country for which the largest number of liberalizing acts were introduced is the USA, at over 3.100. The next positions are taken by Germany, Italy and France, while China occupies ninth place. As a result of its relatively low share and less influence on the global economy, Russia is only $35^{\text {th }}$. In turn, China is the country against which the largest number of inhibitory regulations have been introduced. It is slightly ahead of Germany, the USA and Italy concerning the number of such regulations.

The results show that the values of the effectiveness of regulations are relatively close and vary between 30 and $50 \%$. Two categories may be clearly distinguished: the first comprises only two states (China and Brazil) where the indicator's value is between 40 and $50 \%$. Meanwhile, the results of all other G20 members vary from 30 to $40 \%$.

China is the country with the largest surplus of trade-restricting regulations over liberalizing ones (over 3800). Compared to all the regulations introduced for Chinese businesses, the surplus of regulations inhibiting trade was the highest, and the effectiveness of the regulations was as high as $43 \%$. In no other country with a significant share in international trade has this figure exceeded $40 \%$. This demonstrates that China's growing role in global exports and its strong positive trade balance can be linked to its expansive economic policy. Among the G20 countries, Brazil stands out with the highest effectiveness of regulations.

The next element of the analysis concerns the differences between the number of trade regulations introduced by the G20 members on other states in the world in the period 20092018 (Table 2). These are Type 2 relations. As for liberalizing regulations, the first places are occupied by China, Brazil and India. Their low labor costs and, consequently, their high level of competitiveness mean that liberalizing acts do not pose a threat to them. Moreover, liberalization of imports may improve re-exports, where a significant part is first imported from other countries. As far as restrictive regulations are concerned, the leaders in this respect are large, geopolitically important states, with China, the USA, Germany, India and Russia holding the first five places. 
Table 1. Number of trade regulations introduced by all countries in the world for separate G20 members (2009-2018)

\begin{tabular}{|c|c|c|c|c|c|}
\hline Country & $\begin{array}{l}\text { Total } \\
\text { regulations }\end{array}$ & $\begin{array}{c}\text { Restrictive } \\
H\end{array}$ & $\begin{array}{c}\text { Liberalizing } \\
\qquad L\end{array}$ & $\begin{array}{l}\text { Difference in number of } \\
\text { regulations }[H-L]\end{array}$ & $\begin{array}{l}\text { Effectiveness of } \\
\text { regulations } E R, \%\end{array}$ \\
\hline China & 8933 & 6394 & 2539 & 3855 & 43 \\
\hline Germany & 9346 & 6340 & 3006 & 3334 & 36 \\
\hline USA & 9289 & 6136 & 3153 & 2983 & 32 \\
\hline Italy & 8824 & 6023 & 2801 & 3222 & 37 \\
\hline France & 8653 & 5856 & 2797 & 3059 & 35 \\
\hline United Kingdom & 8240 & 5624 & 2616 & 3008 & 37 \\
\hline Republic of Korea & 8144 & 5529 & 2615 & 2914 & 36 \\
\hline Japan & 8109 & 5458 & 2651 & 2807 & 35 \\
\hline Canada & 7579 & 5264 & 2315 & 2949 & 39 \\
\hline Mexico & 6485 & 4308 & 2177 & 2131 & 33 \\
\hline Saudi Arabia & 2391 & 1920 & 1011 & 909 & 38 \\
\hline South Africa & 5109 & 3325 & 1784 & 1541 & 30 \\
\hline Indonesia & 6269 & 4095 & 2174 & 1921 & 31 \\
\hline Argentina & 4159 & 2708 & 1451 & 1257 & 30 \\
\hline Australia & 5777 & 3842 & 1935 & 1907 & 33 \\
\hline India & 7778 & 5147 & 2631 & 2516 & 32 \\
\hline Brazil & 4393 & 4393 & 2179 & 2214 & 50 \\
\hline Turkey & 5440 & 3722 & 1718 & 2004 & 37 \\
\hline Russia & 4869 & 3261 & 1608 & 1633 & 34 \\
\hline
\end{tabular}

Source: own elaboration based on Global Trade Alert data (www.globaltradealert.org)

In contrast to the Type 1 relations, the number of introduced regulations and their effectiveness is more diversified. The difference between the states with the highest and lowest levels of effectiveness of regulations is $72 \%$. The greatest effectiveness (over 65\%) of such regulations characterizes rich countries such as Japan, Saudi Arabia, Canada, the United States and Germany, where restrictive measures clearly dominate. In the case of China, with the highest number of regulations, the relationship between the inhibiting and liberalizing mechanisms is much more balanced, and the effectiveness ratio is only $19 \%$.

Trade wars between key international actors Trade wars between geopolitical rivals

Hostile actions undertaken between geopolitical rivals and opponents (e.g., USA/EU-Russia, USA-China, USA-Iran, Russia-Ukraine), confirm the return of classical mechanisms of geoeconomics (Luttwak 1990; Findlay \& O'Rourke 2007; Mair 2018). This section will take a closer look at the key moments of the trade wars between the world's greatest powers and the deglobalizing effects they have.

Restrictions against Russia imposed by the US and the EU during the Ukrainian crisis in March 2014 accelerated geopolitically motivated trade wars (Aalto \& Forsberg 2016; Bouwmeester \& Oosterhaven 2017). Until this turning point, unlike the Soviet Union, Moscow had not been subjected to Western sanctions (Makasheva
2016). Initially, actions by Western countries included a wide range of measures against Russian companies and specific politicians and business people. Unlike the subsequent US trade tensions with the EU and China, both sanctions (and Russia's counter-sanctions) were provided due to purely geopolitical reasons: the annexation of Crimea, support for pro-Russian separatists in Donbas, Washington's accusations against Russia concerning interference with the American elections, etc. Russia is no longer invited to G7 summits. The NATO-Russia Council was suspended for several years. The Russian government almost immediately imposed retaliatory trade sanctions on those countries that joined the anti-Russian restrictions. The countersanctions mainly concerned imports of agricultural products. The reduction of imports became the chief driver of price increases and, indirectly, of a deterioration in product quality in Russia (Makasheva 2016). From the very beginning of the sanctions policy against Russia, its authorities have implemented a strategy of import substitution (Tolkachev \& Teplyakov 2018). This is seen as a factor that strengthens state sovereignty, but, on the other hand, it also makes the national economy more isolated in the global economy.

Until 2014, exports to Russia represented $4.25 \%$ of total food exports from EU countries. This share was much higher only for some items. For example, almost one-third of cheese, fruit, vegetables and butter produced in the EU was delivered 
MISCELLANEA GEOGRAPHICA - REGIONAL STUDIES ON DEVELOPMENT

Vol. $25 \cdot$ No. $2 \cdot 2021 \cdot$ pp. 99-109 • ISSN: 2084-6118 • DOI: 10.2478/mgrsd-2020-0051

Table 2. Number of trade regulations introduced by G20 nation states toward all other states in the world (2009-2018)

\begin{tabular}{|c|c|c|c|c|c|}
\hline Country & $\begin{array}{l}\text { Total } \\
\text { regulations }\end{array}$ & $\begin{array}{c}\text { Restrictive } \\
H\end{array}$ & $\begin{array}{c}\text { Liberalizing } \\
\qquad\end{array}$ & $\begin{array}{l}\text { Difference in number of } \\
\text { regulations }[H-L]\end{array}$ & $\begin{array}{l}\text { Effectiveness of } \\
\text { regulations } E R, \%\end{array}$ \\
\hline China & 4781 & 2854 & 1927 & 927 & 19 \\
\hline USA & 2384 & 2065 & 319 & 1746 & 73 \\
\hline Germany & 1950 & 1608 & 342 & 1266 & 65 \\
\hline India & 1352 & 957 & 395 & 562 & 42 \\
\hline Brazil & 1288 & 743 & 545 & 198 & 15 \\
\hline Russia & 1170 & 843 & 327 & 519 & 44 \\
\hline United Kingdom & 1112 & 770 & 342 & 428 & 38 \\
\hline Argentina & 1078 & 759 & 319 & 440 & 41 \\
\hline Italy & 1053 & 716 & 337 & 379 & 36 \\
\hline France & 1027 & 690 & 337 & 353 & 34 \\
\hline Canada & 867 & 786 & 81 & 705 & 81 \\
\hline Australia & 849 & 356 & 49 & 309 & 36 \\
\hline Japan & 682 & 637 & 45 & 592 & 87 \\
\hline Indonesia & 618 & 403 & 215 & 188 & 30 \\
\hline Turkey & 463 & 335 & 128 & 207 & 45 \\
\hline South Africa & 430 & 268 & 160 & 108 & 25 \\
\hline Saudi Arabia & 313 & 286 & 27 & 259 & 83 \\
\hline Republic of Korea & 290 & 209 & 81 & 128 & 44 \\
\hline Mexico & 289 & 198 & 91 & 107 & 37 \\
\hline
\end{tabular}

Source: own elaboration based on Global Trade Alert data (www.globaltradealert.org)

to Russia. Due to Russian counter-sanctions, EU countries took action to stabilize national food markets, reorient production to new markets, and support the most affected producers. The measures taken by the EU weakened the impact that Russia's embargo had on EU exports. One year after its introduction, exports from the EU of those products banned for import by Russia had increased by $4.8 \%$ in May 2015 compared to August 2014. This was due to the geographical reorientation of exports and growing supply to South Korea, China, Turkey, Hong Kong and Egypt (Makasheva 2016). In general, the sanctions imposed on the import of certain groups of goods and the operation of some companies from Russia, as well as the Russian retaliatory sanctions, harmed the volume of trade with the EU. This trend continued in the first two years after 2014 and covered exports, imports and total trade value. In 2016, the value of trade with the EU fell by half compared to 2012 (Fig. 3). However, fluctuations in trade due to purely geopolitical factors did not affect the nature of the relationships, as the trade balance remained unfavorable for the EU. This balance was slightly better in 2019, when it amounted to EUR -66.5 billion. Another key trend that may indicate a weakening of the sanctions' impact is the renewed increase in trade in 2017 and 2018. This resulted from the desire to "normalize" and return to trade relations beneficial to both parties. The available data indicates that Russia is slightly better positioned thanks to the increased value of exports to the EU.
Compared to the strictly economic objectives of US trade restrictions toward partner countries from the Asia Pacific region and the EU (Fetzer \& Schwarz 2019; Larres 2020), trade wars with China undoubtedly have both geopolitical and commercial goals. They are intended to slow down the implementation of China's global strategy in the Xi Jinping era in technology, investment and trade, which is incompatible with American interests (Feldkircher \& Korhonen 2014; Blanchard \& Flint 2017; Pang et al. 2017; Medeiros 2019).

The protectionist measures are subject to different assessments. Some economists claim that trade liberalization and an increase in imports of industrial commodities impose pressure on American wages (Krugman 2007), which serves as one of the arguments for introducing tariffs on Chinese manufactured goods. Nevertheless, in the globalizing world, this issue is more complex. While in the classical trade theories, goods are completely made within one country's borders and shipped to another, much of the US imports from China contain value created in other locations, including American intellectual property (Lovely and Liang 2018). Trump's penchant for tariffs, actions against Huawei, and expansive trade demands have destabilized the broader relationship (Medeiros 2019). Despite divergent views on the strictly economic impact of these activities, they have a rational economic base since they aim to strengthen the national economy by reducing negative effects on imports and reducing the dependence on Chinese goods and technologies. 


\section{EURO billion}

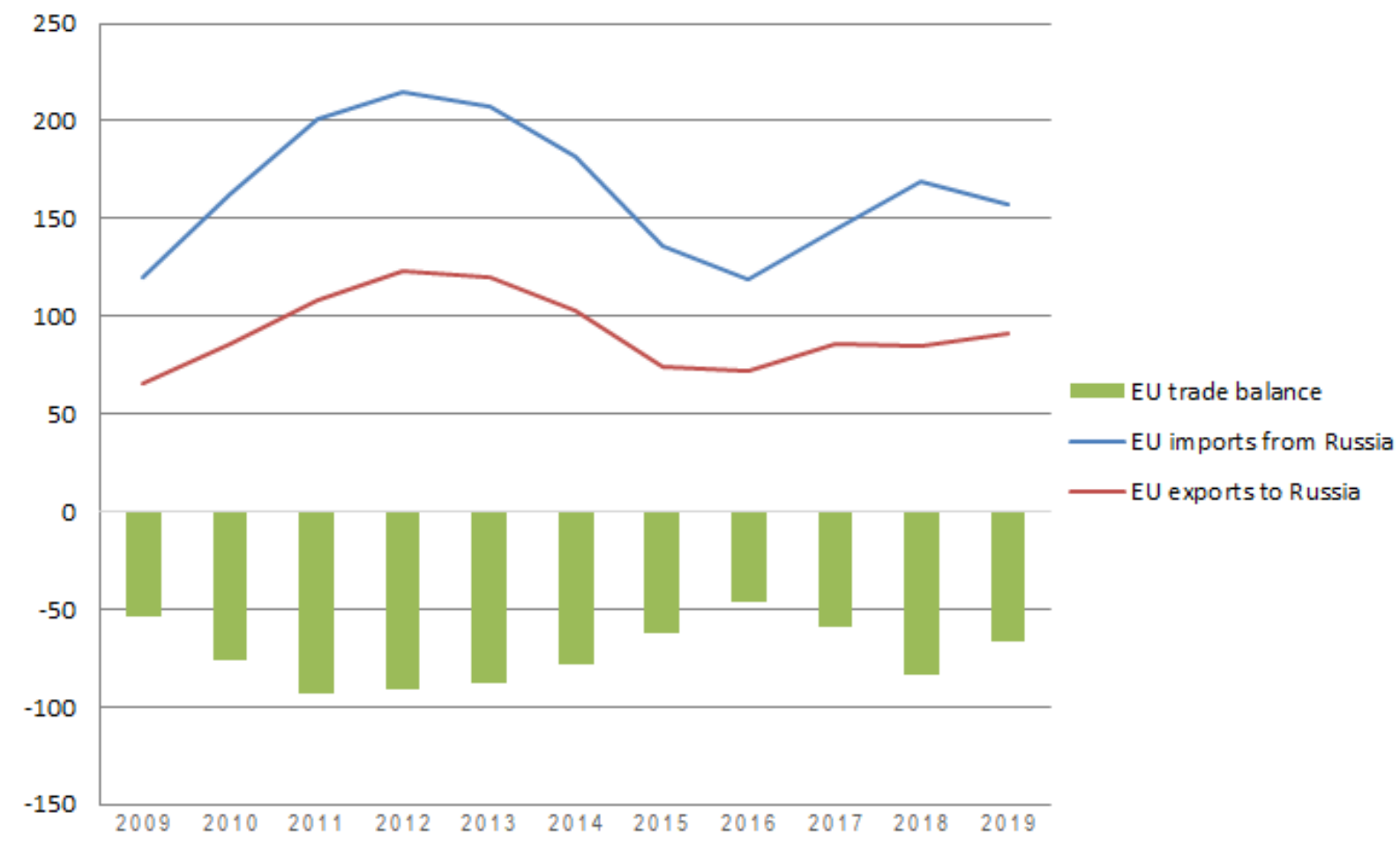

Figure 3. Dynamics of EU-Russia trade in 2009-2018

Source: own elaboration based on Eurostat data (https://ec.europa.eu)

The first half of 2018 saw the most intense exchange of regulations between Washington and Beijing. Early that year, the USA introduced tariffs on imports of Chinese solar panels, washing machines, steel and aluminum. China responded by introducing tariffs on selected US products. According to Global Trade Alert, the most restrictive regulations apply to computing machinery and parts, motor vehicles, trailers and semi-trailers, chemical products, and products of steel, iron and other metals. Protectionist measures reversed the negative values of the US trade balance with China reaching USD -345 billion (Fig. 4). In 2019, the Chinese economy recorded its lowest annual growth rate since 1990 .

The countries affected by various trade barriers have taken steps to geographically reconfigure their exports and imports. In the most significant states, World Bank data shows diverging trends (The World Bank Web Site 2020). Between 2013 and 2018, EU exports recorded an increase of more than $2 \%$, while Russia's exports grew by $5 \%$, with a clear decline in 2016 and 2017 due to difficulties in the first years after the introduction of Western sanctions. Brazil and Turkey also showed an increase in exports. The USA, which traditionally has one of the lowest shares of exports in its GDP, recorded a decline of $1.3 \%$. The downward trend in exports as a percentage of GDP is even more noticeable in China. Since 2016, this indicator has remained below $20 \%$ and is far from the best result achieved in 2006 (36\%).

In turn, the trade wars have not affected the ratio of imports to Russia's GDP, which in the period 2013-18 was still at $20 \%$. The minimization of economic relations with the US has not affected Russia to a great extent due to their relatively small volume. For example, at the end of 2013 , the volume of accumulated Russian investments in the US economy amounted to USD 4.1 billion, while in the Netherlands they are assessed at USD 23.3 billion. At the same time, American investments in Russia were estimated at USD 10.3 billion, while the value of Dutch investments was almost seven times greater (Klinova \& Sidorova 2014). The EU, on the other hand, experienced a more than $2 \%$ increase in imports of goods and services. Some of the EU's largest economies, i.e. Germany, France, Italy and Spain, show a similar trend with comparable values. On the other hand, a decrease in imports was recorded by the USA $(-1.2 \%)$ and China $(-3.3 \%)$ (The World Bank Web Site 2020).

Trade wars between allies and partners

A significant feature of sanctions policies is their use against close trade partners. A typical example are the relations between Russia and Turkey, the two Eurasian forces that were on the way to building a new "strategic axis" (Erşen 2011). Bilateral tensions were accelerated after the military incident in the Turkish-Syrian air border zone in late 2015 , which became a turning point in Russian-Turkish relations. Russia took steps against its Turkish partner, i.e. limiting trips to Turkey for tourist purposes, freezing cooperation in construction projects and restricting imports of Turkish agricultural products. This led to losses for the sanctioned sectors of the Turkish economy and negatively affected Russian consumers. In addition to the direct effect on the decline in trade, the number of Russian tourists in Turkey decreased fourfold in 2016 (Coşkun 2019). In the end, however, the pragmatism of the two parties of that interstate conflict prevailed. Russia and Turkey quickly began to normalize mutual relations, regardless of their complexity and conflicting interests in Syria, the Caucasus and North Africa.

Apart from short-term episodes such as the deterioration in relations between Russia and Turkey in 2015-2016, many other events accompany the harming of cooperation between close partners in international relations, including revision of its previously established principles. At the end of the 2010s, the 
MISCELLANEA GEOGRAPHICA - REGIONAL STUDIES ON DEVELOPMENT

Vol. $25 \cdot$ No. $2 \cdot 2021 \cdot$ pp. 99-109 • ISSN: 2084-6118 • DOI: 10.2478/mgrsd-2020-0051

\section{USD billion}
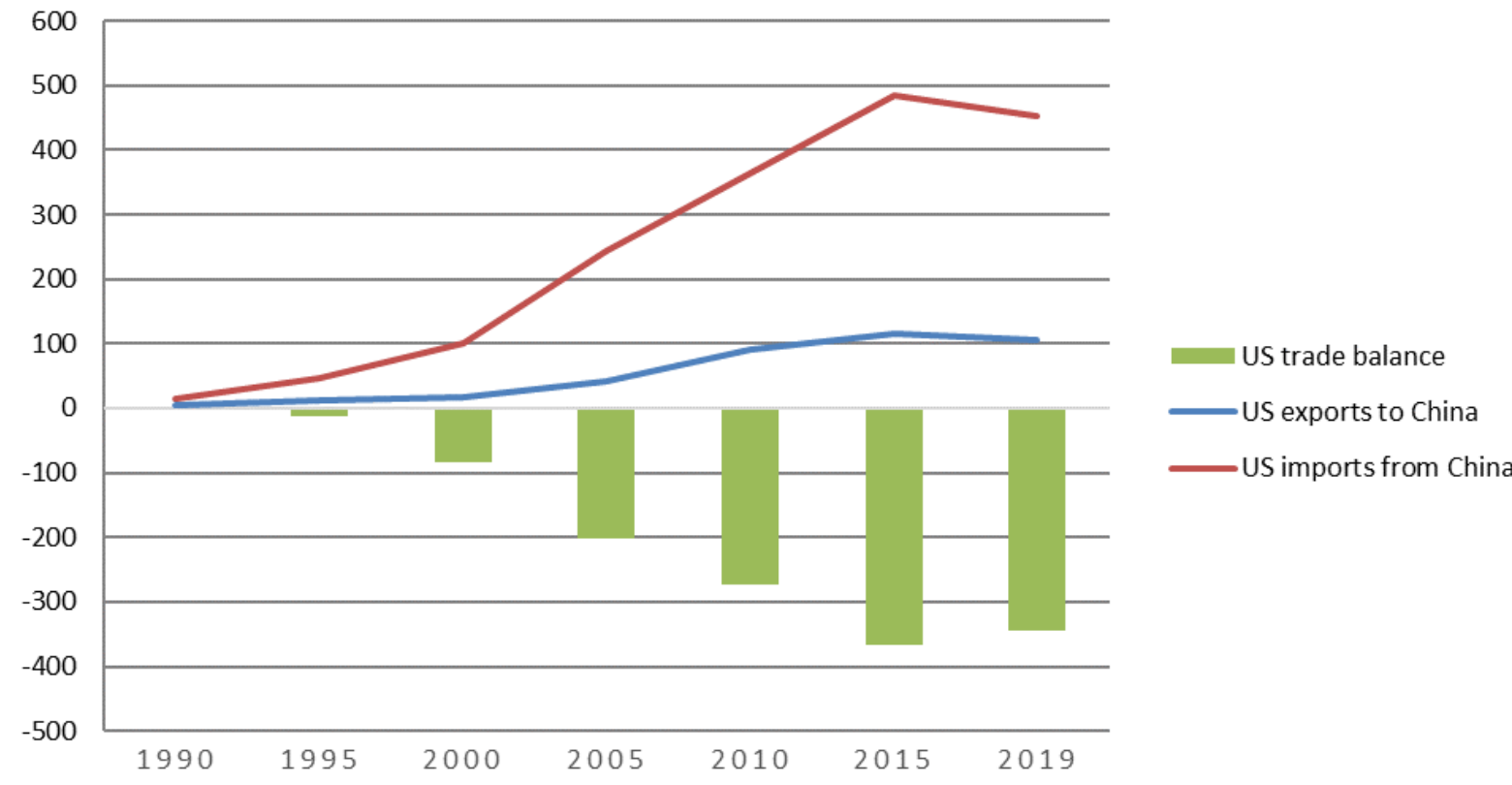

Figure 4. Dynamics of trade of goods between USA and China, 1990-2018

Source: own elaboration based on United States Census Bureau data (www.census.gov/foreign-trade/balance/c5700.html)

most active policy, both protectionist toward the domestic market and sanctioning, is being pursued by the United States in their "[...] exceptionally assertive trade policy geared toward achieving a 'free, fair and reciprocal' (with an emphasis on that last word) trading system" (Consequences of US trade policy on EU-US trade relations and the global trading system 2018, p. 4). After Trump came to power, a trade war was waged - and not only against Russia, China and Iran, but also aimed at close economic partners and geopolitical allies. To protect its internal market, the US started to introduce duties on various goods imported from the EU, Japan, China, Mexico, Canada and other countries. Consequently, negotiations toward a comprehensive Transatlantic Trade and Investment Partnership with the European Union were suspended, a re-negotiation of NAFTA was launched, and the US-Korea agreement was amended (Consequences of US trade policy on EU-US trade relations and the global trading system 2018).

The Asia Pacific region was also highly affected by the new protectionist line. It was the main geographical direction of US economic expansion (Wenzhao 1999; Parameswaran 2014). The administration of Barack Obama developed the Trans-Pacific Partnership agreement as an effective tool for this policy, bringing together the USA and eleven other countries, without China's participation (Yakovlev 2017). In 2015, the US trade deficit with the countries of this region amounted to USD 178 billion in 2015 (Scott and Glass 2016). This negative trend was Trump's key argument for the American withdrawal from the Trans-Pacific Partnership agreement for free trade in 2017 (Yakovlev 2017).

To conclude this concise empirical overview, the growing number of geopolitically motivated sanctions and countersanctions, in which companies from both sides of the conflict suffer economic losses, needs to be highlighted. The larger negative effects are mainly exerted on the weaker (in economic terms) partners, including the reduction in foreign investment. Nevertheless, Western states' restrictions on Russia, Iran or China do not alter their policy on key regional geostrategic and security issues. In turn, economic tensions between the leading global and regional powers are often temporary. The measures antagonizing mutual relationships do not always drastically change long-term bilateral relations.

\section{Discussion and conclusion}

This article aimed to examine how the practical rapprochement between geopolitics and geoeconomics in international politics of the world's largest states affects their trade relations and in what way it changes the global order established after the end of the Cold War. An attempt was also made to contextualize the impact of trade wars on globalization processes in a broader geographical scope, which goes beyond the analyses of growing restrictions in US-China relations. The lack of full and comparable data (Evenett 2019), particularly concerning the geographical directions, kind and duration of sanctions, impede the elaboration of a systemic and comprehensive picture of this element of trade wars.

This article has examined only specifically selected empirical aspects of the current trade wars that illustrate introduced trade barriers and sanctions. Based on the regulations that inhibit and liberalize the trade exchange of $\mathrm{G} 20$ members, two types of relations were identified. An index of the effectiveness of regulations that balance both types of relations was proposed. It reflects the cumulative difference in the liberalizing and restrictive impacts of the totality of regulations. According to the obtained results, the greatest effectiveness of Type 1 relations was found for inhibitory regulations against China. In turn, the highest effectiveness of regulations introduced on other countries (Type 2) was characteristic of Japan, Saudi Arabia, Canada and the USA, which proves their protectionist attitudes.

As empirical analysis confirmed, in the late 2010s, there was an increase in governments' activities described as trade wars on a global and regional scale. This phenomenon undoubtedly requires additional research, but the results obtained allow us to draw some more general conclusions about megatrends in bilateral and multilateral trade wars. In fact, all countries that are important in global development are initiators of trade wars. The countries with the largest share of the global economy are also the 
most active in creating both harmful and liberalizing regulations of Type 1 and Type 2. This may be due to the multitude of types of goods they trade and their numerous geographical directions of foreign economic relations.

It is noteworthy that the studied period seems too short to give an unambiguous answer as to whether we are facing a deep and long-term crisis of globalization or whether the series of trade wars is more of a transitional period. Although empirical data are also insufficient to solve this dilemma, we can certainly argue that concepts such as "the end of globalization" (James 2001; Jacoby 2018) are are as yet unwarranted. One can agree with Findlay and O'Rourke (2007, p. 535) that "history suggests that globalization is a fragile and easily reversible process, with implications not just for international trade, but for the international division of labor and economic growth as well." In the context of increasing trade wars, this means that King's thesis of a return of history is fully justified. As the author claims, globalization concerns the return of global powers, and it simply failed to deliver prosperity for all (King 2018). Nonetheless, contemporary globalization is not over. The observed stagnation can instead be explained in terms of deglobalization (Bello 2004; Karunaratne 2012) and the breaking rules of hyperglobalization (Balsa-Barreiro et al. 2020; Subramanian \& Kessler 2013) as an effect of the massive re-politicization of economic relations (Dieter 2014).

\section{References}

Aalto, P \& Forsberg, T 2016, 'The structuration of Russia's geo-economy under economic sanctions', Asia Europe Journal, no. 14, pp. 221-237.

Amadi, L 2020, 'Globalization and the changing liberal international order: A review of the literature', Research in Globalization, no. 2, pp. 1-9.

Balsa-Barreiro, J, Vié, A, Morales, AJ \& Cebrián, M 2020, 'Deglobalization in a hyper-connected world', Palgrave Communications, vol. 6, no. 28, pp. 1-4.

Bello, W 2002, Deglobalization: Ideas for a New World Economy, Zed Books, London and New York.

Berthou, A, Jardet, C, Siena, D \& Szczerbowicz, U 2019, The macroeconomic implications of a global trade war. https:// voxeu.org/article/macroeconomic-implications-global-tradewar) [03.08.2020]

Bethlehem, D 2014, 'The End of Geography: The Changing Nature of the International System and the Challenge to International Law', The European Journal of International Law, vol. 25, no. 1, pp. 19-24.

Blanchard, J-MF \& Flint, C 2017, 'The Geopolitics of China's Maritime Silk Road Initiative', Geopolitics, vol. 22, no. 2, pp. 223-245.

Bongardt, A \& Torres, F 2018, 'What Should Be the EU's Approach to Global Trade?', Intereconomics, vol. 53, no. 5, pp. 245-249.

Bourantonis, D \& Wiener, J (eds.) 2015, The United Nations in the New World Order. Palgrave Macmillan, London.

Bouwmeester, MC \& Oosterhaven, J 2017, 'Economic impacts of natural gas flow disruptions between Russia and EU', Energy policy, no. 106, pp. 288-297.

Brzoska, M 2015, 'International sanctions before and beyond UN sanctions', International Affairs, vol. 91, no. 6, pp. 13391349.

Consequences of US trade policy on EU-US trade relations and the global trading system. European Parliament, Policy Department for External Relations Directorate General for External Policies of the Union, November 2018.

Cortright, D \& Lopez, G 2000, The Sanctions Decade: Assessing UN Strategies in the 1990s, Lynne Rienner Publishers.
As Luttwak specified (1990: 20), "In the past, when commercial quarrels evolved into political quarrels, they could become military confrontations almost automatically; and in turn military confrontations could readily lead to war." Even though the scale of ongoing trade wars is unlikely to be analogous to historical examples in terms of exchange value, there is, so far, no indication of the real danger of an explosion and large-scale military conflict between superpowers. Nevertheless, the global order and the rules of international relations are undergoing deep, far-reaching transformations. The importance of state borders is once again returning, stopping the quest for a borderless world. The greatest powers have attempted to re-organize the rules of interactions of globally integrated national and transnational entities and are causing a crisis of globalization. However, it is too early to confirm the thesis of the end or fall of globalization. Despite the rise in mutual restrictions between the major military and economic powers making the world a less predictable place, the number of liberal trade regulations in effect is still relatively large, and the system of international economic relations remains more open and interdependent than any other in history.

\section{ORCID}

Valentin Mihaylov (iD https://orcid.org/0000-0002-5888-6583

Sławomir Sitek (1D https://orcid.org/0000-0003-1430-4251
Coşkun, BB 2019, 'Turkey's Relations with Russia after the Failed Coup: A Friend in Need of a Friend Indeed?', New Middle Eastern Studies, Vol. 9, no. 1, pp. 36-52.

Gottemoeller, R 2007, 'The Evolution of Sanctions in Practice and Theory', Survival, vol. 49, no. 4, pp. 99-110.

de Oliveira, JAP \& Jing, Y (eds.) 2020, International Development Assistance and the BRICS. Palgrave Macmillan, Singapore. DOI: 10.1007/978-981-32-9644-2.

Diamond, P (ed.) 2019, The Crisis of Globalization: Democracy, Capitalism and Inequality in the Twenty-First Century, I.B.Tauris, London and New York.

Dieter, H 2014, The Return of Geopolitics / Trade Policy in the Era of TTIP and TPP, Friedrich Ebert Stiftung, Berlin.

Doxey, M 1980, Economic Sanctions and International Enforcement, Oxford University Press, New York.

Drezner, D 2003. 'How Smart Are Smart Sanctions?', International Studies Review, vol. 5, no. 1, pp. 107-110.

Economic Sanctions. Sharpening a Vital Foreign Policy Tool, 2017. Atlantic Council. Available from: <https:// atlanticcouncil.org/in-depth-research-reports/issue-brief/ economic-sanctions-sharpening-a-vital-foreign-policytool/>. [27.12.2019].

Erşen, E 2011, 'Turkey and Russia: An emerging 'strategic axis' in Eurasia?', EurOrient, np. 35-36, pp. 263-285.

Eurostat Web Site. Available from: https://ec.europa.eu. [30.04.2020].

Evenett, SJ 2019, 'Protectionism, state discrimination, and international business since the onset of the Global Financial Crisis', Journal of International Business Policy, no. 2, pp. 9-36.

Feldkircher, M \& Korhonen, I 2014, 'The rise of China and its implications for the global economy: evidence from a global vector autoregressive model', Pacific Economic Review, vol. 19 , no. 1 , pp. 61-89.

Fetzer, T \& Schwarz, C 2019, 'Tariffs and Politics: Evidence from Trump's Trade Wars', CESifo Working Paper, no. 7553.

Findlay, R \& O'Rourke, KH 2007, Power and Plenty: Trade, War and the World Economy in the Second Millennium, Princeton University Press, Princeton, NJ. 
Fukuyama, F 1992, The End of History and the Last Man, Free Press, New York.

Gens, B 2019, 'Germany's Russia policy and geo-economics: Nord Stream 2, sanctions and the question of EU leadership towards Russia', Global Affairs, vol. 5, no. 4-5, pp. 315-334.

Global risk 2015, World Economic Forum.

Going It Alone? Trade Policy After Three Years of Populism 2019, Centre for Economic Policy Research, London.

Gordon, J 2011, 'Smart Sanctions Revisited', Ethics \& International Affairs, vol. 25, no. 3, pp. 315-335.

Greig, JM 2002, 'The End of Geography?: Globalization, Communications, and Culture in the International System', Journal of Conflict Resolution, vol. 46, no. 2, pp. 255-243.

Grossman, GM \& Helpman, E 1995, 'Trade wars and trade talks', Journal of Political Economy, vol. 103. no. 4, pp. 675-708.

Harvey, D 1989, The Condition of Postmodernity: An Enquiry into the Origins of Cultural Change, Blackwell, Cambridge, MA.

Hillebrand, EE 2010, 'Deglobalization scenarios: who wins? Who loses?', Global Economy Journal, vol., 10, no. 2, pp. 9-36.

Jacoby, DS 2018, Trump, Trade, and the End of Globalization, Praeger, Santa Barbara and Denver.

James, H 2001, The End of Globalization - Lessons from the Great Depression, Harvard University Press, Cambridge.

Joyner, CC 2003, 'United Nations Sanctions after Iraq: Looking Back to See Ahead', Chicago Journal of International Law, vol. 4, no. 2, pp. 329-353.

Kaplan, RD 2012, The Revange of Geography, Random House, New York.

Kaplinsky, R \& Farooki, M 2011, 'What Are the Implications for Global Value Chains When the Market Shifts from the North to the South?' International Journal of Technological Learning, Innovation and Development, vol. 4, no. 1-3, pp.

Karunaratne, ND 2012, 'The Globalization-Deglobalization Policy Conundrum', Modern Economy, vol. 3, no. 4, pp. 373-383.

King, SD 2018, Grave New World: The End of Globalization, the Return of History, Yale University Press, New Haven and London.

Klinova, M \& Sidorova, E 2014, 'Ekonomicheskiye sanktsii i ikh vliyaniye na khozyaystvennyye svyazi Rossii s Evropeyskim soyuzom' ['Economic sanctions and their impact on economic ties between Russia and the European Union'], Voprosy ekonomiki [lssues of economy], no. 12, pp. 67-79.

Krugman, P 2007, Trouble with trade. Available from: <https:// www.nytimes.com/2007/12/28/opinion/28krugman.html?ex $=1356498000 \&$ en $=59380$ e4088506422\&ei $=5124 \&$ partner $=$ permalink\&exprod=permalink>. [16.08.2020].

Larres, K 2020, 'Trump's trade wars: America, China, Europe, and global disorder', Journal of Transatlantic Studies, vol. 18, no. 1, pp. 103-129.

Lechthaler, W \& Mileva, M 2018, 'Who Benefits from Trade Wars?', Intereconomics, vol. 53, no. 1, pp. 22-26.

Lovely, ME \& Liang, Y 2018, 'Trump's tariffs primarily hit international supply chains, undermining the U.S.'s technological competitiveness', Policy Briefs, vol. PB 18-12, pp. 1-10.

Luke, TW 1996, 'Governmentality and contra governmentality: rethinking sovereignty and territoriality after the Cold War'. Political Geography, vol. 15, no. 6-7, pp. 491-507.

Luttwak, ED 1990, 'From Geopolitics to Geo-Economics: Logic of Conflict, Grammar of Commerce', The National Interest, no. 20 , pp. 17-23.

Mack, A \& Kahn, A 2000, 'The Efficacy of UN Sanctions', Security Dialogue, vol. 31, no. 3, pp. 279-292

Mair, S 2018, 'From geopolitics to geoeconomics', in Germany and the World 2030: What will change. How we must act, eds. S Mair, D Messner \& L Meyer, Econ, Berlin. <https://deutschland-und-die-welt-2030.de/en/article/fromgeopolitics-to-geoeconomics/> [10.08.2020].

Makasheva, NA 2016, 'Vvedenie [Introduction]', in Vliianie sanktsii na ekonomiku Rossii. Otsenki rossiiskikh i zarubezhnykh spetsialistov [The Impact of Sanctions on the Russian Economy: Estimates of Russian and Foreign Specialists], eds. NA Makasheva \& EA Pekhtereva, Tsentr sotsialnykh nauchno-informatsionnykh issledovanii [Institute of Scientific Information for Social Sciences], Moskva, pp. 4-8.

McCabe, B 2012, Geography is Dead: How American Lost Its Sense of Direction, Common Ground Publishing, Champaign, IL.

Medeiros, ES 2019, 'The Changing Fundamentals of US-China Relations', The Washington Quarterly, vol. 42, no. 3, pp. 93-119.

Mukherji, R 2009, 'The State, Economic Growth, and Development in India', India Review, vol. 8, no. 1, pp. 81-106.

National Secutiry Strategy, 2015, Washington. Available from: <https://obamawhitehouse.archives.gov/sites/default/ files/docs/2015_national_security_strategy_2.pdf>. [27.12.2019].

Parameswaran, P 2014, 'Explaining US Strategic Partnerships in the Asia-Pacific Region: Origins, Developments and Prospects', Contemporary Southeast Asia, vol. 36, no. 2, pp. 262-289

Qiu, LD, Zhan, C \& Wei, X 2019, 'An analysis of the China-US trade war through the lens of the trade literature', Economic and Political Studies, vol. 7, no. 2, pp. 148-168.

Pape, RS 1997, 'Why Economic Sanctions Do Not Work', International Security, vol. 22, no. 2, pp. 90-136.

Pang, X, Liu, L \& Ma, S 2017, 'China's Network Strategy for Seeking Great Power Status', The Chinese Journal of International Politics, 2017, vol. 10, no. 1, pp. 1-29.

Porzecanski, AC 2015, Brazil's Place in the Global Economy, in Brazil on the Global Stage. eds. O Stuenkel \& MM Taylor, Palgrave Macmillan, New York.

Scott, RE \& Glass, E 2016, 'Trans-Pacific Partnership, currency manipulation, trade, and jobs', EPI Briefing Paper, no. 420. Available from: <www.epi.org/files/2016/tpp-jobs-final.pdf> [30.04.2020].

Steinbock, D 2018, 'U.S.-China Trade War and Its Global Impacts', China Quarterly of International Strategic Studies, vol. 4, No. 4, pp. 515-542.

Subramanian, A \& Kessler, M 2013, 'The Hyperglobalization of Trade and Its Future', Working Paper Series, WP13-6, Peterson Institute for International Economics, Washington,

The Global Trade Alert Web Site 2020. Available from: <www. globaltradealert.org $>$ [05.01.2020]

The US-China Trade War: A Timeline, February 26, 2020, Available from: <www.china-briefing.com/news/the-uschina-trade-war-a-timeline/>. [06.03.2020]

The World Bank Web Site 2020, World Bank Open Data. Available from: <https://data.worldbank.org>. [05.01.2020].

Toal, G 1997, 'At the End of Geopolitics? Reflections on a Plural Problematic at the Century's End', Alternatives, vol. 22, no. 1, pp. 33-55.

Tolkachev, S \& Teplyakov, A 2018, Import Substitution in Russia. Problems of Economic Transition, vol. 60, no. 7, pp. 545-577, DOI: 10.1080/10611991.2018.1551033

United States Census Bureau Web Site 2020. Available from: $<$ www.census.gov/foreign-trade/balance/c5700.html> [02.03.2020].

van Bergeijk, PAG 1995, 'The Impact of Economic Sanctions in the 1990s. The World Economy', The World Economy, vol. 18, no. 3, pp 443-455.

Wenzhao, T 1999, 'U.S. interests in the Asia-Pacific region', Peace Review, vol. 11, no. 3, pp. 423-429 
Wigell, M 2016, 'Conceptualizing Regional Powers' Geoeconomic Strategies: Neo-Imperialism, Neo-Mercantilism, Hegemony, and Liberal Institutionalism', Asia Europe Journal, vol. 14, no. 2, pp. 135-151.

Yakovlev, P 2017, "Faktor Trampa” i menyayushchiysya oblik globalzatsii' [,The Trump factor" and the changing face of globalization], Mirovaya ekonomika i mezhdunarodnyie otnoshenia [World Economy and International Relations], vol. 61 , no. 7 , pp. 5-14. 